\title{
How do Companies Engage in Cooperation on Product and Process Innovation in the Context of the Transformation to an Industry 4.0?
}

\author{
By Pascal Boer ${ }^{*} \&$ Ditmar Ihlenburg*
}

\begin{abstract}
The transformation to an Industry 4.0, which is in general seen as a solution to increasing market challenges, is forcing companies to radically change their way of thinking and to be open to new forms of cooperation. In this context, the opening-up of the innovation process is widely seen as a necessity to meet these challenges, especially for small and medium enterprises (SMEs). The aim of the study therefore is to analyze how cooperation today can be characterized, how this character has changed since the establishment of the term Industry 4.0 at Hanover Fair in 2011 and which cooperation strategies have proven successful. The analysis consists of a quantitative, secondary data analysis that includes country-specific data from 35 European countries of 2010 and 2016 collected by the European Commission and the OECD. The research, focusing on the secondary sector, shows that multinational enterprises MNEs still tend to cooperate more than SMEs, with a slight overall trend towards protectionism. Nevertheless, there is a clear tendency towards the opening-up of SMEs. In this regard, especially universities, competitors and suppliers have become increasingly attractive as cooperation partners for SMEs.
\end{abstract}

Keywords: Collaboration, Cooperation, Industry 4.0, Innovation, MNE, Network, SME.

\section{Introduction}

The research area Industry 4.0 has been extensively studied in recent years. Industry 4.0 - the so-called 4th industrial revolution - is thereby largely seen as a solution to the increasing challenges companies are facing (e.g. the internationallization of competition, increasing market complexity and uncertainty, shortening product lifecycles, increasing changes in customer values and trends towards individualization) (Batz et al. 2018, Vassiliadis 2017, Reichwald and Piller 2009). According to Vassiliadis, Industry 4.0 will in this context provide new opportunities to meet these increasing challenges for companies (Vassiliadis 2017).

The term Industry 4.0 was described by the Plattform Industrie 4.0 as "the reform and reorganization of value chains to a networked coordination" (Platform Industrie 4.0 2015). This intelligent cooperation between suppliers, producers and customers is based on new information and communications technologies (ICT) and is designed to enhance the value of cooperation (Saniuk and Saniuk 2018, Felser et al. 2015). According to Baum, Kieninger and Kagermann, these

\footnotetext{
*Graduate Student, HTWG Konstanz - University of Applied Sciences, Germany.

"Professor, HTWG Konstanz - University of Applied Sciences, Germany.
} 
ICT and -related methods, e.g. Cyber-Physical Systems, Big Data Analytics and Machine Learning, enable internal and external knowledge to be used to create and enhance innovations (Kieninger et al. 2015, Baum 2013, Kagerman et al. 2013).

Following Châlons and Dufft, innovativeness represents an essential challenge in the context of the digitalization (Châlons and Dufft 2016). Anyway, this is not a new insight. Schumpeter had already stated at the beginning of the 20th century that innovations are drivers for growth and economic success (Schumpeter 1934).

According to Reichwald and Piller, innovation is even becoming increasingly important (Reichwald and Piller 2009). Efforts in research and development (R\&D) are urgently needed to achieve temporary monopolistic profits and gain global competitiveness (Semolic and Steyn 2018, Gassmann 2006). In this context, a shift away from classical internal R\&D activities towards external R\&D activities could already be observed in the early 2000s (Christensen et al. 2005, Rigby and Zook 2002).

Required competences and resources for innovations, such as cognitive skills and expertise as well as capacities are, according to Schikora, usually not available in adequate quantities in-house (Schikora 2014). Companies are therefore advised to be open to external innovations and establish alliances with peers and clusters (Batz et al. 2018, Christensen et al. 2005, Rigby and Zook 2002). The opening-up of the innovation process can, according to Gassmann, be considered an empirical trend (Gassmann 2006). Open Innovation, a method of innovation management, is a corresponding approach that not only relies on knowledge and skills of the internal R\&D department, but also uses external resources (Piller et al. 2017).

Open Innovation, which was defined by Chesbrough in 2003, describes the usage of knowledge inflows and outflows to accelerate innovation (Chesbrough 2003). According to Chesbrough, this refers to a strategy that allows the systematic use of open search and tendering methods or new forms of cooperation with external partners to integrate external knowledge (Chesbrough 2006). Kolk et al. take this concept even further to a hyper cooperation with several cooperation partners in ecosystems (Kolk et al. 2017).

Following Schikora, the implementation of new Industry 4.0 technologies, especially Big Data Analytics, could support the creation of innovations on a completely new scale (Schikora 2014). Big Data Analytics, which essentially relies on the analysis of a large amount of structured and unstructured data provided by cyber physical systems, recently enjoys great attention and is widely seen as the next threshold of innovative value creation (Baum 2013, Kagermann 2013).

The real-time analysis of a big amount of data is intended to be used for the development of innovation ideas and designs, the identification of potential partners and supporting the decision-making process (Baum 2013, Kagermann 2013). Co-creation under the banner of Big Data illustrates the key importance of value networks, in which companies operate in complex network of interconnections and relationships involving a variety of stakeholders (Del Vecchio et al. 2017). The realization of this vision is, however, still hampered by several barriers that have to be dealt with (Ezell 2018). 
Following a study of Ezell in 2018, many manufacturers, in particular SMEs, simply lack the know-how on where to start with the implementation of Industry 4.0 technologies (Ezell 2018). The implementation of these technologies fundamentally depends, in accordance to Kane et al., on the digital maturity of the company (Kane et al. 2017). Corresponding maturity models that focus on supporting companies to achieve a higher level of digital maturity are currently very popular for implementing Industry 4.0 in a step-by-step improvement process (Mettler 2011).

The study by Mittal et al. from 2018, which examines current maturity models regarding the requirements of SMEs, shows significant deficits in the suitability of the examined maturity models for SMEs and furthermore reveals a gap in the corresponding field of research (Mittal et al. 2018). Two major deficits were identified within this study (Mettler 2011, Bischoff et al. 2015). (1) Maturity models focus MNEs and supports SMEs only slightly towards the implementation of Industry 4.0. (2) No maturity model has fulfilled the requirements of SMEs by considering alliances and cooperation as a factor of maturity. Similar deficits in the field of research of innovation for SMEs were identified by West, Boger and Hossain (Hossain 2015, West and Boger 2014).

This knowledge gap related to SMEs is controversial, as SMEs play an important role in economic value creation (Müller et al. 2017). SMEs comprise over $99 \%$ of all businesses in the European Union which create a gross valueadded share of about 50\% of the total European economy (Müller et al. 2017, Bundesministerium für Wirtschaft und Energie 2014). According to Müller et al., SMEs require a unique strategy in the implementation of Industry 4.0 due to fundamental differences compared to MNEs in terms of structure, processes and the availability of resources (Müller et al. 2017).

This study therefore focuses on the analysis of cooperation of SMEs and MNEs with their cooperation partners in order to meet this identified research gap. Following research questions (RQ) are to be examined within the paper:

- RQ1: How can cooperation between companies and their partners be characterized based on the entered cooperation?

- RQ2: How has the character of cooperation changed since the establishment of the term Industry 4.0?

- RQ3: Do companies intensify their efforts in the field of intellectual property (IP) protection when cooperating and which strategies are successful in terms of value creation?

The aim is to examine the character of cooperation between companies and their partners (e.g. customers, suppliers and universities) and how the character has changed since the establishment of the term Industry 4.0 at the Hanover Fair in 2011. Furthermore, the study aims to identify if companies intensify their efforts in IP protection when cooperating and which cooperation strategies are successful in terms of value added.

For this purpose, the literature is to be reviewed with regard to indications of the characteristics of cooperation and then to be compiled in scientifically verifiable hypotheses. Then, country-specific data collected by the European 
Commission and the OECD will be examined using a correlation analysis and a regression analysis to examine the relationship between defined variables and the change of its characteristics. This includes the latest available data from 35 European countries from 2010 and 2016.

\section{Literature Review}

The ability to innovate is a key challenge in the age of digitization (Châlons and Dufft 2016). In this context, the availability of constantly improving ICT as well as the change in values in the world of business and society are creating increasing competitive pressure on companies (Piller and Reichwald 2009).

According to Châlons and Dufft, a radical change in mindset must now take place in which companies must revise their conventional ways of thinking and interacting as well as their traditional management approaches and mechanisms (Châlons and Dufft 2016). New forms of cooperation and leadership are necessary to leverage innovative forces within companies (Châlons and Dufft 2016). In this context, according to Semolic and Steyn, MNEs will not exclusively dominate the markets, which offer space for innovative SMEs to become global players (Semolic and Steyn 2018). Thereby, different reasons arise for companies to deepen or reduce the establishment of cooperation.

\section{General Reasons for Companies to Participate in Cooperation}

Overall, a trend towards opening-up the innovation process can be observed according to Gassmann et al. (Gassmann et al. 2010). Following Semolic and Steyn, companies are increasingly participating in cooperative projects to reduce their associated R\&D costs and risks and at the same time increase their own innovativeness (Semolic and Steyn 2018).

Piller summarizes the increase in efficiency and effectiveness of an open innovation process in four aspects (Piller 2004). Besides the reduction of development costs ("Cost-to-market") and the period from development to market launch ("Time-to-market") cooperating can also lead to an increase in market acceptance ("Fit-to-market") and the level of novelty or attractiveness ("New-tomarket") of an innovation (Piller 2004). For example, Procter and Gamble was able to improve the success rate of its products by $50 \%$ and its R\&D efficiency by $60 \%$ through their cooperation approach (Enkel et al. 2009). Furthermore, companies can increase their strategic flexibility and gain access to new knowledge (Gassmann 2006). As a result, companies that do not participate in cooperation and miss out on these advantages are confronted with serious disadvantages (Enkel et al. 2009).

Nevertheless, there are numerous risks and arguments against an intensification of cooperation. The results of the study by Enkel et al., in which 107 European companies were interviewed, reveal that companies are primarily inhibited to cooperate by risks such as the loss of knowledge, higher costs of coordination, the loss of self-control and higher complexity. This coincides with 
Dahlander and Gann, according to which companies that rely too heavily on external resources become dependent on their external partners and may be faced with hidden costs of communication and control (Dahlander and Gann 2010, Stuermer et al. 2009). In addition, the study of Enkel et al. identifies significant barriers, including difficulties in finding suitable partners and lack of time and financial resources (Enkel et al. 2009). According to the broad literature, the degree of participating in cooperation differs greatly among small and large companies (West and Boger 2014, Vossen 1998, Acs and Audretsch 1990).

\section{Specific Reasons for Cooperation with regard to Company Size}

Cooperation strategies and becoming part of global value chains are often the only opportunity for SMEs to compensate their deficits in innovativeness (Batz et al. 2018, Zeng et al. 2010). SMEs are by their nature hampered in their innovation capacity by a deficit of financial resources, restricted ability to recruit skilled employees, inadequate control structures, limited access to ICT, lack of external partners and small portfolios (Batz et al. 2018). Employees in SMEs, for example, are deeply involved in the everyday operative business which leaves little time and space for creativity towards innovation (Meroño and López 2013, Nieves et al. 2016). Following Spithoven et al., cooperating can address these challenges by increasing the chances for SMEs to launch new products or services (Spithoven et al. 2013). Although there are several reasons for deepening cooperation for SMEs, there are also reasons for not intensifying cooperation.

Following Hossain, SMEs tend to be less active in open innovation compared to MNEs due to their specific attributes in terms of structure, strategy and resources, such as capital (Hossain 2015). Open innovation, for example, constitutes a long and cost-intensive process that often involves hidden transaction costs (Hossain 2015). In accordance to the transaction cost theory such hidden costs for instance consist of costs for the exchange of information, negotiations on transactions and contracts as well as for the monitoring and implementation of agreements (Rao 2003). According to Batz et al., SMEs, despite the lack of resources, often do not align their internal structures to avoid medium or long-term failures (Batz et al. 2018). Moreover, most SMEs do not follow a systematic innovation process (O'Regan et al. 2006). Cooperation would therefore lead to a limitation of the requirements demanded by SMEs for flexible structures and processes.

However, cooperation is of special importance for MNEs due to higher competitive pressure and more complex organisational structure compared to SMEs (Zypries 2017). MNEs, thanks to their resources and structures, are able to build up diversified innovation portfolios and spread risks through cooperation (Van de Vrande et al. 2009).

Nevertheless, there are also reasons why MNEs should not intensify their cooperative alliances. Müller et al. states that large companies are often considered too powerful to be a business partner (Müller et al. 2017). Furthermore, internal R\&D departments represent strategic assets that lead to entry barriers for potential competitors (Van de Vrande et al. 2009). In addition to these reasons for and 
against the intensification of cooperation, cooperative activities can also be distinguished with regard to the external partner and their significance for cooperation (Ceccagnoli et al. 2010, Teirlinck et al. 2010).

\section{Suitable Partners for Cooperation}

West and Boger reviewed the literature for sources of external knowledge and identified them in supplier, customer, competitor and university communities (West and Boger 2014). In this context, especially suppliers and universities have been mentioned as important cooperation partners in the literature.

Suppliers as partner of cooperation can improve the success of innovation by applying their specialized competences (Dahlander and Gann 2010). According to Hagedoorn, especially an early integration of suppliers can increase the innovative success (Hagedoorn 1993). Furthermore, universities are considered to be an important source of new knowledge, which has a considerable influence on the productivity of R\&D activities (Cohen et al. 2002). Although cooperation entails multiple advantages, cooperating can result in serious strategic risks.

Opening-up the innovation process means that knowledge may also be released externally and used by others (Dahlander and Gann 2010). Patents are in theory one way of protecting intellectual property in this regard. Nevertheless, in the case of cooperation, it is very difficult to allocate and protect intellectual property, especially when there are weak regional IP rights (Baldwin and Henkel 2014, Dahlander and Gann 2010).

\section{Hypotheses}

All in all, a broad spectrum of literature was reflected within the literature review. For this purpose, 65 relevant papers and scientific articles were identified within the literature research and then used to indicate the character of cooperation. The following section deals with compiling the characteristics of cooperation in scientifically valid hypotheses to capture the research questions and goals posed in section 1 . In order to derive hypotheses, the qualitative indications from the literature review regarding the character of cooperation are settled in a hypotheses construct (see Figure 1).

Figure 1 shows the hypothesis construct that is to be examined within the paper. The linkages shown in Figure 1 represent the defined hypotheses based on which the cooperation between companies in terms linear correlation will be examined. The construct is to be seen in such a way that the positive mathematical operator (+) refer to positive correlation and the negative operator (-) to negative correlation in arrow direction. 
Figure 1. Hypotheses Construct and Framework for the Analysis
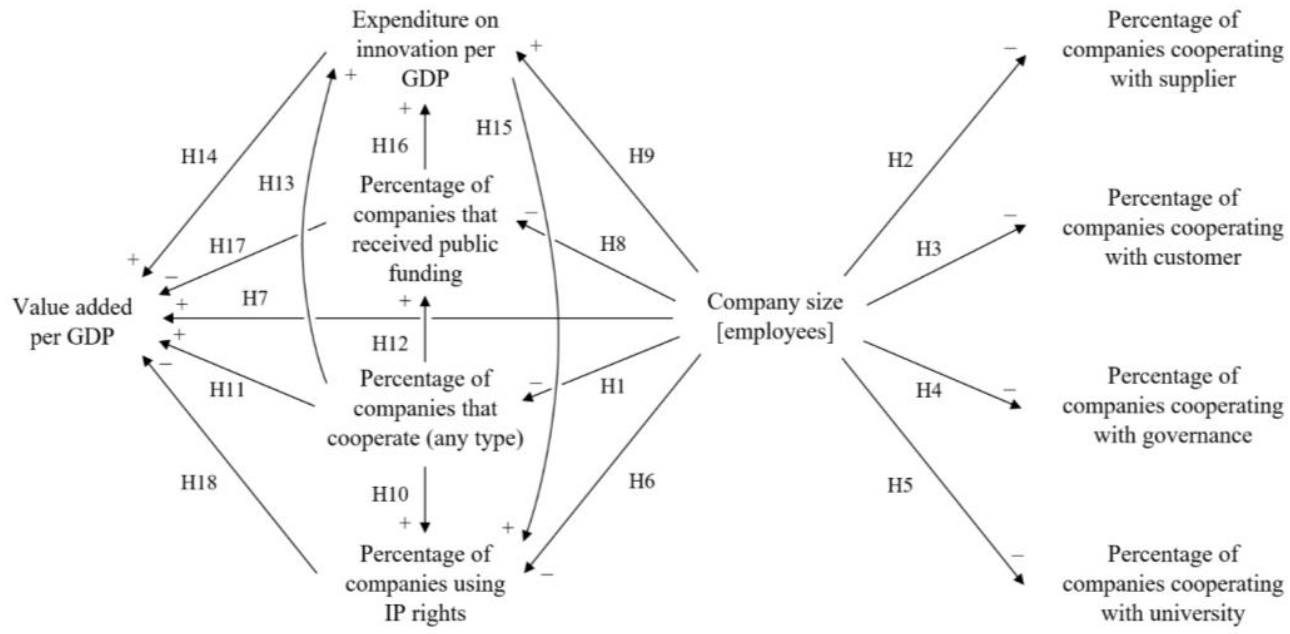

The variables are derived from the defined research questions and the selected secondary data and are transferred to the following hypotheses based on the evidence from the literature:

- H1: The percentage of companies cooperating in any type is decreasing with company size.

- H2: The percentage of companies cooperating with suppliers is decreasing with company size.

- H3: The percentage of companies cooperating with customers is decreasing with company size.

- H4: The percentage of companies cooperating with governance is decreasing with company size.

- H5: The percentage of companies cooperating with university is decreasing with company size.

- H6: The percentage of companies using IP rights is decreasing with company size.

- H7: The value added per GDP is increasing with company size.

- H8: The percentage of companies received public funding is decreasing with company size.

- H9: The expenditure on innovation per GDP is increasing with company size.

- H10: The percentage of companies using IP rights is increasing with the percentage of companies cooperating (any cooperation).

- H11: The value added per GDP is increasing with the percentage of companies cooperating (any cooperation).

- H12: The percentage of companies received public funding is increasing with the percentage of companies cooperating (any cooperation).

- H13: The expenditure on innovation per GDP is increasing with the percentage of companies cooperating (any cooperation).

- H14: The value added per GDP is increasing with the expenditure on innovation per GDP.

- H15: The percentage of companies using IP rights is increasing with the expenditure on innovation per GDP. 
- H16: The expenditure on innovation per GDP is increasing with the percentage of companies received public funding.

- H17: The value added per GDP is increasing with the percentage of companies received public funding.

- H18: The value added per GDP is increasing with the percentage of companies using IP rights.

In the following, a correlation analysis is carried out to answer these hypotheses in terms of gaining information regarding RQ1 and RQ3 concerning the characteristics and change of cooperation. In this context, H1 to H5 correspond to RQ1 and H6 to H18 apply for RQ3. The aim is to find significant correlation between the defined variables in order to deduce the cooperative characteristics. In addition, a regression analysis is used to address RQ2 and to show how the character of cooperation has changed within the last years.

After the scientific literature has been examined with regard to cooperation and valid scientific hypotheses have been defined, a description of the methods used as well as the results is given next.

\section{Methodology}

Based on the literature review, different incentives for SMEs and MNEs to deepen or reduce the establishment of cooperation can be considered. This section therefore tends to examine a suitable research method and sources for clarifying the mentioned thematic. Subsequently, relevant data must be collected and evaluated. Based on the evaluated data the research questions are then attempted to be answered.

\section{Framework}

Regarding the focus on SMEs, a paper of Piccarozzi is consulted that analysis the existing literature on the subject of Industry 4.0 for SMEs. According to this study, $45 \%$ of the empirical studies are quantitative studies, with almost $80 \%$ of these studies being conducted on individual countries only (Piccarozzi et al 2018). In order to address this gap in the field of research this paper will be applied in the form of a quantitative study among European countries.

The framework for this study is given in the secondary analysis of cooperative and financial data of 35 European countries in the years of 2010 and 2016. This period covers the last data collection before the establishment of the term of Industry 4.0 in 2011 and the data of 2016 representing the latest data on this thematic and country-specific focus.

\section{Data Sample}

Database for this approach comprises the statistical databases Eurostat and OECD Statistic of the European Commission and the OECD. In total, 73 datasets with various data, including cooperative and financial data, were generated and 
converted into one master dataset. Within the study, 35 European countries are covered, which represents the maximum number of European countries with available data at the time of data collection. The study focuses on the secondary sector. This selection assumes of Tjahjono and Van de Vrande et al. according to which Industry 4.0 will initially and mostly impact on manufacturing (Tjahjono et al. 2017, Van de Vrande et al. 2009). In this context, the data belongs to process and product innovative SMEs and MNEs without a specific focus on a certain phase in value creation. In regard to the separation of companies in SMEs and MNEs a classification of the collected data is conducted based on the categorization of the European Commission.

The widely used categorization of companies, as defined by the European Commission, is based on company size, turnover and profit (European Commission 2014). Accordingly, companies are considered small if they count a maximum of 49 employees and a turnover and profit of less than 10 million euro. Medium-sized enterprises are characterized by 50 to 249 employees and a turnover of 10 to 50 and a profit of 10 to 43 million euros.

Anyway, the classification of companies in the paper is based on the practical approach of the European Commission. Based on this practical approach of the European Commission, only the number of employees is considered as classification factor for data analysis.

\section{Measure Methods}

The selection of a variable for measuring the characteristics of cooperation is based in particular on the study of Michelino et al. (Michelino et al. 2014). Within this study, appropriate measurement methods for openness are identified and evaluated from literature.

On this basis, the intensity of cooperation - the share of companies that cooperate - is chosen for the main characterization of cooperation. This measure can be very easily derived from the selected secondary data and has, compared to monetary measures, the advantage that there are primary conclusions about cooperation. In addition, cooperation is also to be determined based on financial data, such as expenditure on R\&D and value added. This is done in accordance of RQ3 which is intended to measure the economic success of cooperation. Thereby, expenses on R\&D are used in relation to GDP which is, according to Michelino et al., a common measure used for the innovation performance of European countries (Michelino et al. 2014). Similarly, value added is also used in relation to GDP in order to obtain standardized variables. In addition, the share of companies that received funding or applied for IP protections are quantified. This is done to clarify the questions whether financial incentives encourage companies to cooperate and if companies intense their efforts for IP protection when cooperating.

Data Analysis

Firstly, the data is analyzed based on a correlation analysis of the defined variables to verify the posed hypotheses. In addition, this is a suitable method for carrying out fundamental research, since there is a lack of research in this field. 
Within the correlation analysis, all variables are to be checked pairwise for correlations and the results are to be shown in a correlation matrix. Due to the given metric and ordinal data of the dataset the Pearson as well as the Spearman correlation coefficient is used. The respective correlations are to be tested for significance using a one-sided p-value test with an error probability of 5\%.

Additionally, an examination of the changes in the degree of cooperation between the years 2010 and 2016 is carried out. A box plot diagram is to be used to show these changes on the basis of different cooperation partners.

In addition, this change is to be analyzed based on company size. For this purpose, a regression analysis is applied. Based on the data of 2010 and 2016, the regression gradients for these years are to be compared. Therefore, the regression gradients will first be normalized using the standard adjustment for the dependent and independent variables and then be compared.

\section{Results}

The results of the correlation analysis are shown in Table 1. Within this correlation matrix, the first column represents the Spearman correlation coefficient between the tested variables, whereas the remaining values show of Pearson correlation coefficients. The values show predominantly positive correlations with, however, different significances.

The shares of companies cooperating in 2010 and 2016 show a highly significant positive correlation with company size, based on Spearman correlation coefficients of 0.730 and 0.633 . Similarly, the correlation coefficients between the percentage of companies that cooperated with various partners (enterprises in group, suppliers, customers, competitors, universities and government) during these years and company size show positive values with highest significance ( $\mathrm{p}$ value lower than $0.1 \%$ ). The share of companies received public funding in 2016 also correlates positively with company size (Spearman correlation coefficient of 0.212), even if only moderate significantly. Another significant linear correlation exists between the percentage of companies received European Union funding in 2016 and company size (0.272), whereas there is a high positive correlation between central government funding and company size in 2016 (0.325). There are also highly significant, positive correlations between expenditure on innovation per GDP and company size (0.628), as well as in-house (0.618) and external R\&D expenditure per GDP $(0.605)$ with company size in 2016 . The share of companies that use any form of IP rights is also highly significant and positively related to company size (0.607), as are value added per GDP (0.803) and turnover per GDP (0.818) of 2016.

Furthermore, there is a highly significant, positive correlation between the the share of companies that received public funding in 2016 and the percentage of companies cooperating at any type (Pearson correlation coefficient of 0.394). The correlation coefficient between expenditure on innovation per GDP in 2016 and the percentage of companies that cooperated at any type is positive and highly significant (0.443), as well as the percentage of companies used any form of IP 
right protections (0.539) and value added per GDP (0.448) with percentage of companies cooperated.

Beyond that, there is also a positive and highly significant correlation between the expenditure for innovations per GDP and the share of companies that use any type of IP right protections (0.453) as well as value added per GDP (0.604) in 2016.

Despite these findings, there is no significant correlation between the percentage of companies that received public funding and expenditure on innovations per GDP (Pearson correlation of 0.103). There is also no significant correlation between the percentage of companies that received public funding and value added per GDP (0.098).

Lastly, there is a high significant, positive correlation between value added per GDP in 2016 and the percentage of companies that cooperate at any type (correlation coefficient of 0.432 ). This is also the last relevant correlation for answering the first research question and for the posed hypotheses.

The results of the correlation analysis on the basis of the assumed statistical pvalue of 5 percent lead to the following hypotheses being accepted and rejected.

Regarding hypotheses $\mathrm{H} 1$ to $\mathrm{H} 6$ and $\mathrm{H} 8$, a significant correlation between the variables can be established. But since the direction of this correlation oppose the tested hypotheses, $\mathrm{H} 1$ to $\mathrm{H} 6$ and $\mathrm{H} 8$ cannot be accepted. Hypotheses $\mathrm{H} 7$ and $\mathrm{H} 9$ to H15 as well as H18, however, can be accepted under the defined error probability.

The correlations for $\mathrm{H} 16$ and $\mathrm{H} 17$ do not show sufficient significance, according to which neither the hypotheses nor the zero hypotheses can be accepted or rejected.

Now that the correlation analysis has been completed it is analyzed how the character of cooperation has changed since the establishment of the term Industry 4.0 in 2011 until 2016. For this purpose, the data will be analyzed by the percentage of companies cooperating with various partners in 2010 and 2016. The results are shown in Figure 2.

The average percentage of companies that cooperated in any form decreased, contrary to the general view of the literature, by $2.12 \%$ from $23.60 \%$ to $24.10 \%$ between 2010 and 2016. However, the analysis of cooperation with various cooperation partners does not show a decline for all forms of cooperation in total.

The largest drop in the percentage of companies that cooperate is seen in the cooperation with customers $(-23.02 \%)$, followed by the cooperation with competitors $(-18.68 \%)$ and the government $(-12.09 \%)$. The largest increase in cooperation was with suppliers, with a percentual increase of only $2.12 \%$. Cooperation with companies in the enterprise group (-0.69\%) and with universities $(+0.77 \%)$ hardly changed in total.

After a slight decline in the overall share of companies that cooperate has been revealed, it is to be shown how the character of cooperation, based on company size, changed within the years from 2010 to 2016. For this purpose, the shares of cooperating companies are analyzed within a regression analysis in relation to company size, based on different cooperation partners. Company size (ordinal scale) classifying small, medium and large enterprises, is, in accordance to the practical categorization of the European Commission, expressed in 3 ranks. The regression analysis is shown in Figure 3. 
Vol. 7, No. 1

Boer \& Ihlenburg: How do Companies Engage in Cooperation ...

Table 1. Correlation Matrix between Analysed Variables

\begin{tabular}{|c|c|c|c|c|c|c|c|c|c|c|c|c|c|c|c|c|c|c|c|c|c|c|c|c|c|c|}
\hline 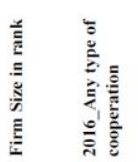 & 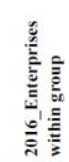 & 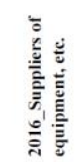 & 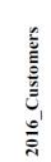 & 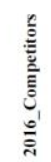 & 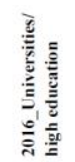 & 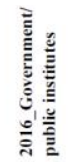 & 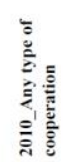 & 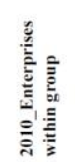 & 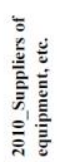 & 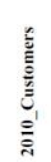 & 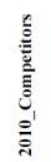 & 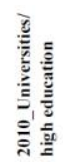 & 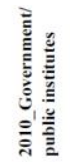 & 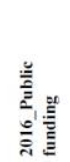 & 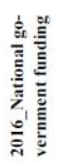 & 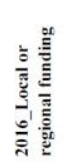 & 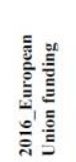 & 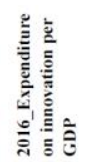 & 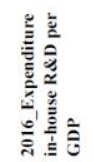 & 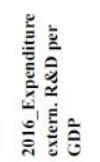 & 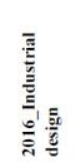 & 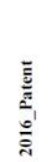 & 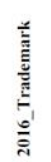 & 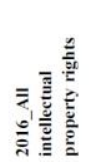 & 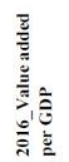 & 该 \\
\hline
\end{tabular}

Firm Size in rank

$1,000^{* * *}$

2016_Any type of cooperation $\quad 0,633^{* * * *} \quad 1,000^{* * *}$

2016_Enterprises within group $\quad 0,736^{* * *} \quad 0,875^{* * *} \quad 1,000^{* * *}$

2016_Suppliers of equipment, $\quad 0,602^{* * * *} \quad 0,924^{* * * *} \quad 0,819^{* * * *} 1,000^{* * *}$

2016_Customers $\quad 0,579^{* * * *} \quad 0.878^{* * *} \quad 0,790^{* * *} \quad 0,881^{* * * *} \quad 1,000^{* * *}$

2016_Competitors $0.531^{* * *} \quad 0,719^{* * * *} 0,666^{* * *} \quad 0,801^{1 * * *} 0,848^{* * *} \quad 1,000^{* * *}$

2016_Universities/ $\quad 0,700^{* * *} \quad 0,829^{* * * *} \quad 0,87^{* * *} \quad 0,766^{* * * *} \quad 0,817^{* * * *} \quad 0,719^{* * *} \quad 1,000^{* * * *}$

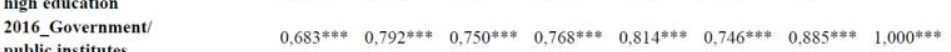

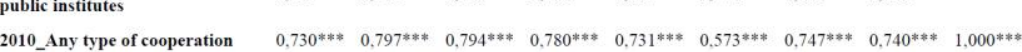

2010_Enterprises within group $\quad 0,798^{* * *} \quad 0,782^{* * *} \quad 0,891^{* * *} \quad 0,766^{* * * *} \quad 0,764^{* * * *} \quad 0,681^{* * *} \quad 0,822^{* * * *} \quad 0,81^{* * *} \quad 0.890^{* * * *} \quad 1.000^{* * *}$

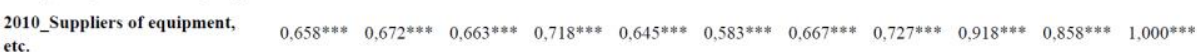

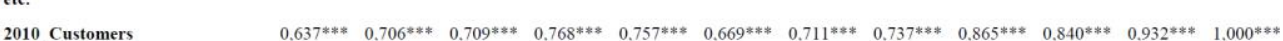

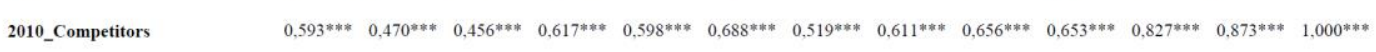

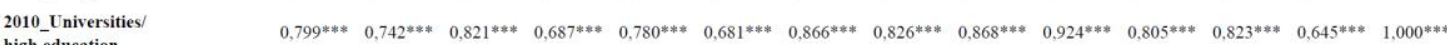

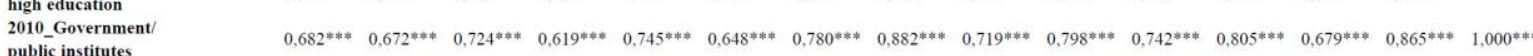

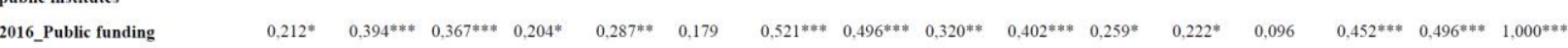

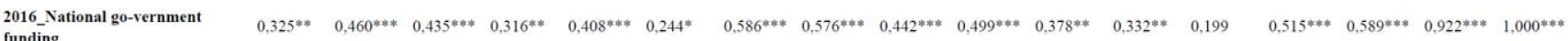

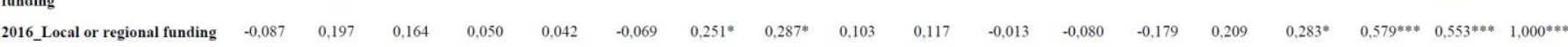

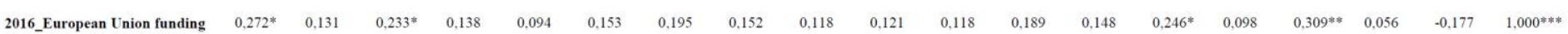

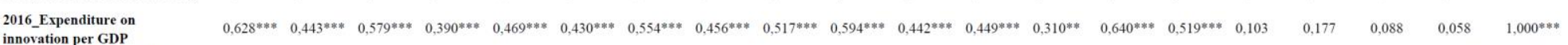

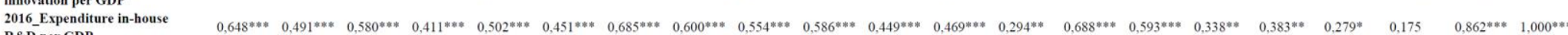

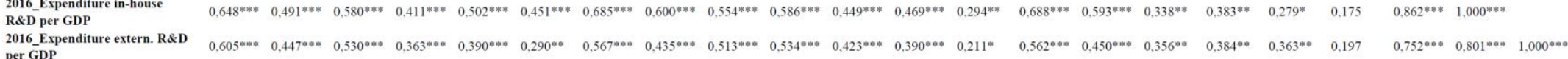

2016_Industrial design

2016_Patent

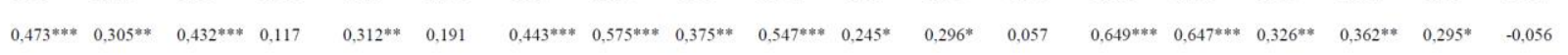

2016_Trademark

2016_All intellectual property

rights

2016_Value added per GDP

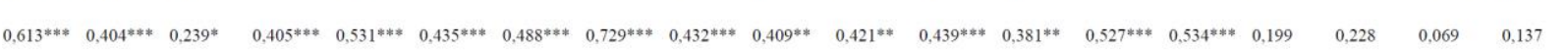

2016_Turnover per GDP

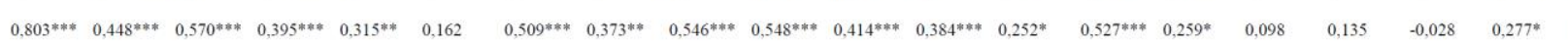

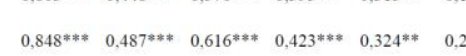

Source: Data based on European Commission 2019 and OECD 2019. 
Figure 2. Share of Companies Cooperating by Different Types of Partners in 2010 and 2016 in Percent

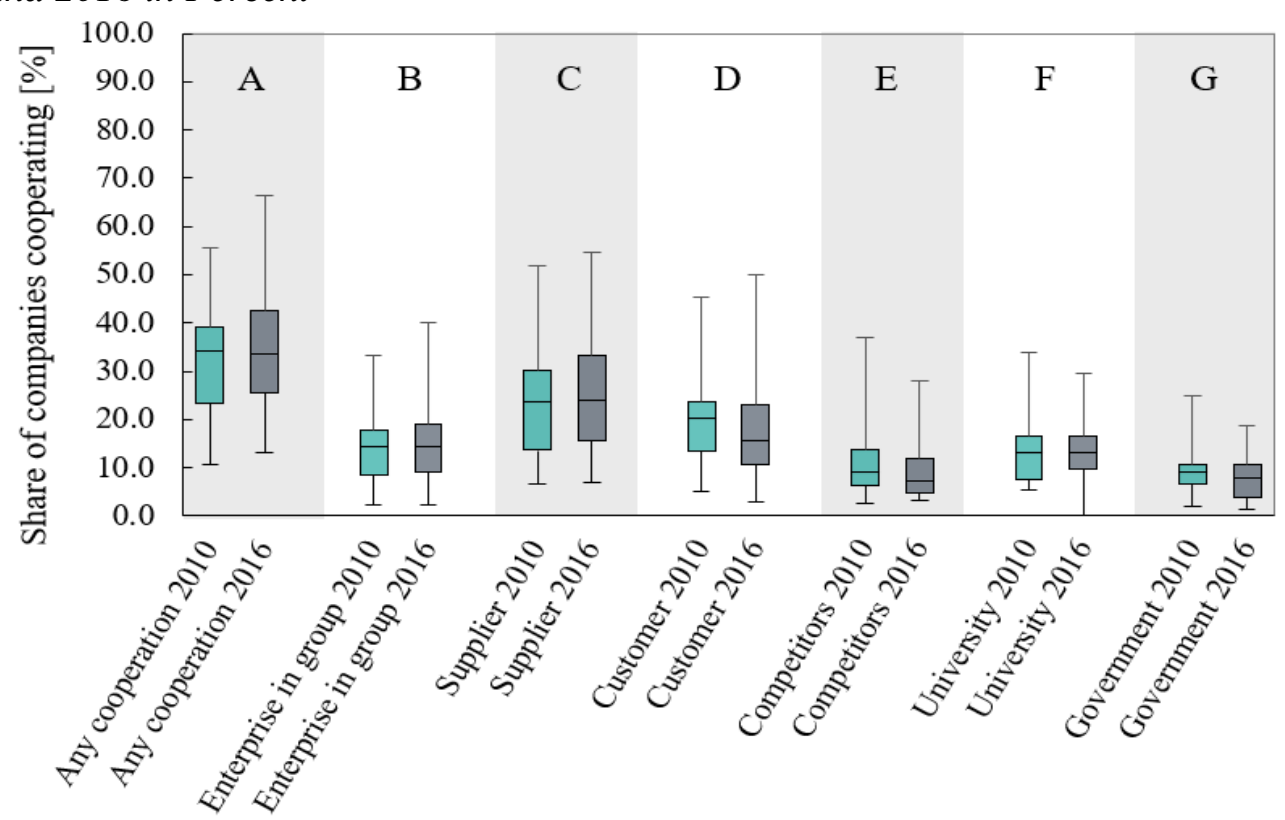

Source: Data based on European Commission 2019 and OECD 2019.

Figure 3. Regression Analysis between Cooperation and Company Size by Different Partners in 2010 and 2016 (A-G: All Significant)

A Regression of cooperating (any type) and company size in 2010 and 2016

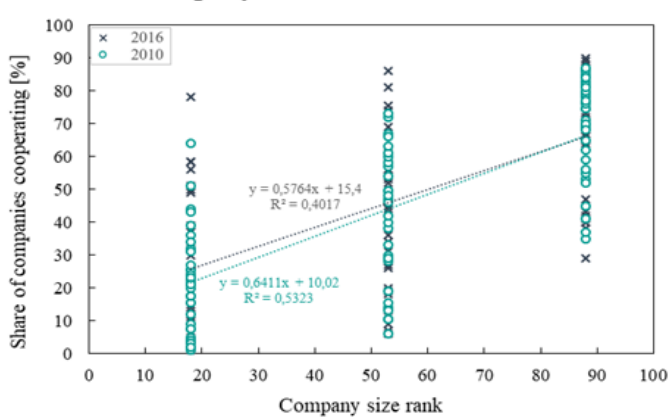

C Regression of cooperating with supplier and company size in 2010 and 2016

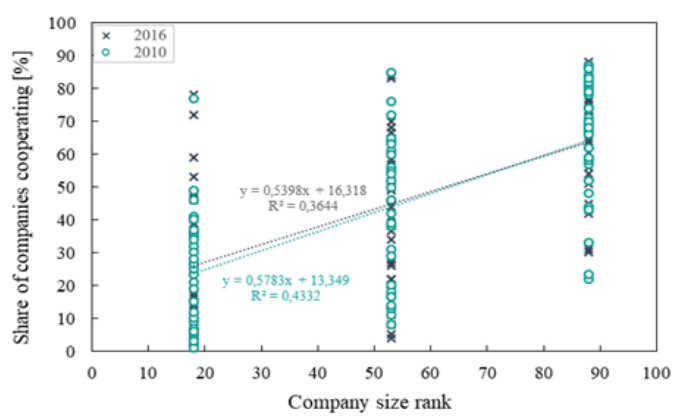

B Regression of cooperating with enterprise in group and company size in 2010 and 2016

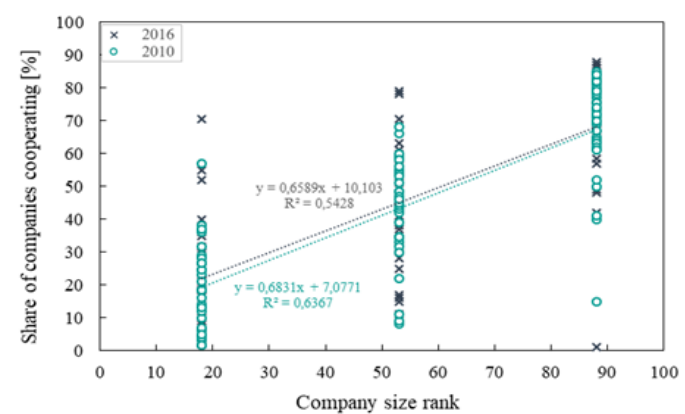

$\mathrm{D}$ Regression of cooperating with customer and company size in 2010 and 2016

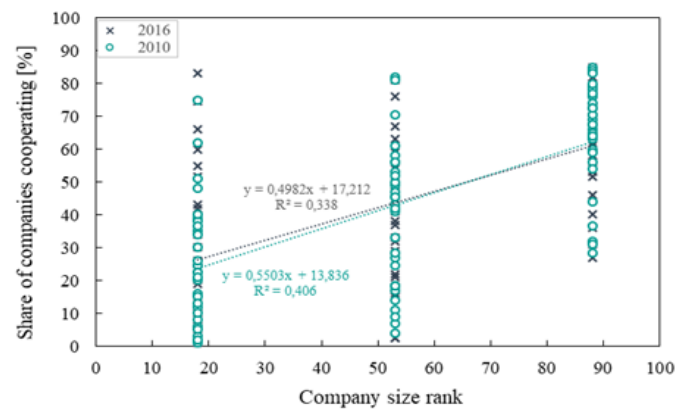



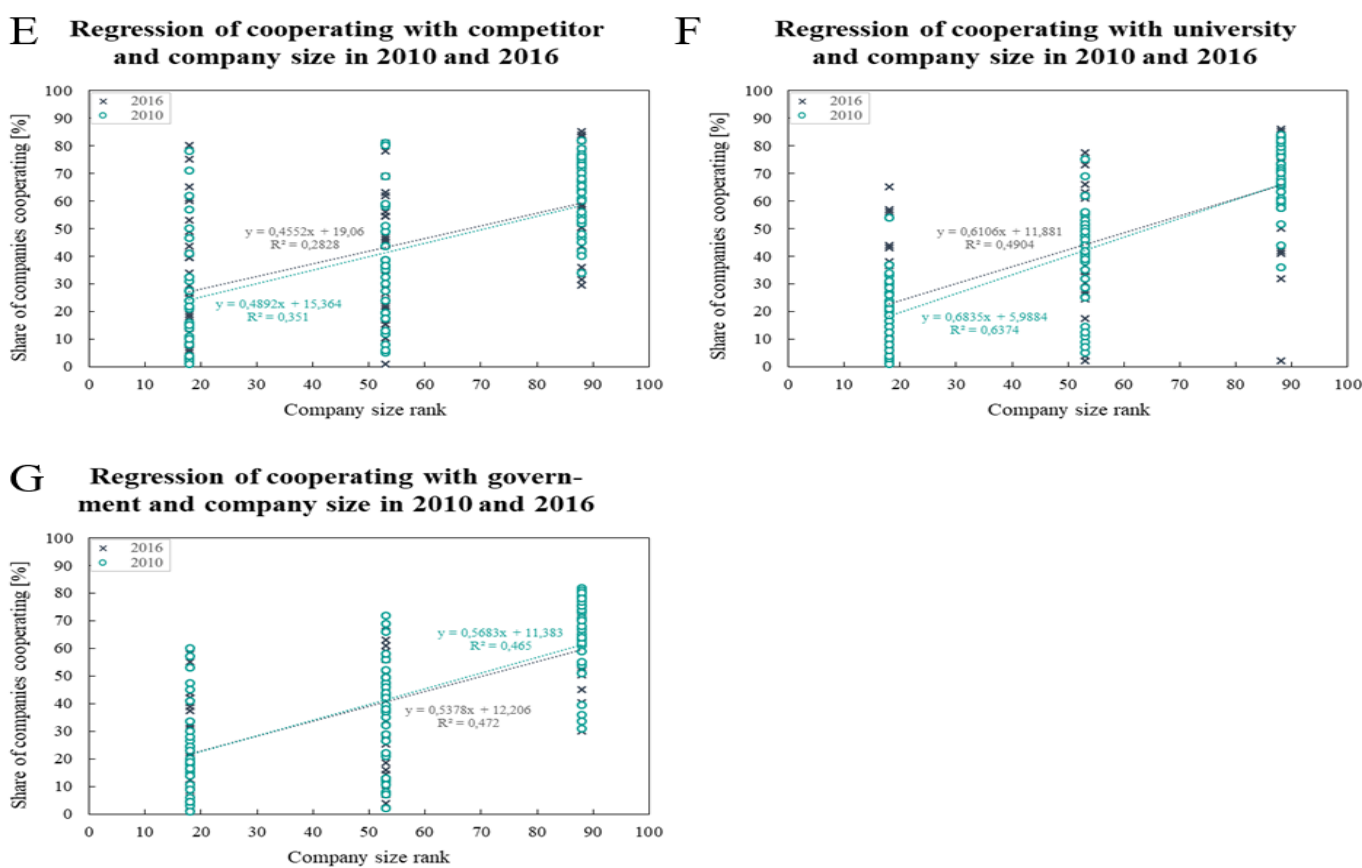

The regression analysis between the share of cooperating companies and company size shows positive regression coefficients for all examined cooperation partners and the respective years. This indicates that the share of cooperating companies rises as company size increases.

However, the regression gradients mainly declined between 2010 and 2016, measured by the standardized coefficients. The standardized regression coefficients and the percentual changes are shown in Table 2.

Table 2. Results of the Regression Analysis

\begin{tabular}{|c|c|c|c|c|c|c|c|}
\hline Value & $\begin{array}{c}\text { Any type } \\
\text { of co- } \\
\text { operation }\end{array}$ & \begin{tabular}{|c} 
Enterprises \\
within \\
enterprise \\
group \\
\end{tabular} & \begin{tabular}{|c|}
$\begin{array}{c}\text { Suppliers } \\
\text { of } \\
\text { equipment, } \\
\text { etc. }\end{array}$ \\
\end{tabular} & $\begin{array}{c}\text { Customers } \\
\text { from } \\
\text { private } \\
\text { sector } \\
\end{array}$ & $\begin{array}{l}\text { Competitors } \\
\text { of the same } \\
\text { sector }\end{array}$ & $\begin{array}{c}\text { Universities } \\
\text { /high } \\
\text { education } \\
\text { institutions } \\
\end{array}$ & $\begin{array}{c}\text { Government/public } \\
\text { research } \\
\text { institutes }\end{array}$ \\
\hline \multicolumn{8}{|c|}{ ( } \\
\hline $\begin{array}{l}\text { Std. } \\
\text { Dev. } \mathrm{x}\end{array}$ & 28.58 & 28.66 & 28.58 & 28.41 & 28.66 & 28.32 & 28.40 \\
\hline $\begin{array}{l}\text { Std. } \\
\text { Dev. y }\end{array}$ & 25.11 & 24.53 & 25.11 & 24.53 & 23.67 & 24.25 & 23.67 \\
\hline Gradient & 0.64 & 0.68 & 0.58 & 0.55 & 0.49 & 0.68 & 0.57 \\
\hline Intercept & 10.02 & 7.08 & 13.35 & 13.84 & 15.36 & 5.99 & 11.38 \\
\hline $\begin{array}{l}\text { Std. } \\
\text { Gradient }\end{array}$ & 0.73 & 0.80 & 0.66 & 0.64 & 0.59 & 0.80 & 0.68 \\
\hline \multicolumn{8}{|l|}{2016} \\
\hline $\begin{array}{l}\text { Std. } \\
\text { Dev. x }\end{array}$ & 28.57 & 28.40 & 28.40 & 28.63 & 28.66 & 28.47 & 28.76 \\
\hline $\begin{array}{l}\text { Std. } \\
\text { Dev. Y }\end{array}$ & 25.98 & 25.40 & 25.40 & 24.54 & 24.53 & 24.82 & 22.51 \\
\hline Gradient & 0.58 & 0.66 & 0.54 & 0.50 & 0.46 & 0.61 & 0.54 \\
\hline Intercept & 15.40 & 10.10 & 16.32 & 17.21 & 19.06 & 11.88 & 12.21 \\
\hline $\begin{array}{l}\text { Std. } \\
\text { Gradient }\end{array}$ & 0.63 & 0.74 & 0.60 & 0.58 & 0.53 & 0.70 & 0.69 \\
\hline \multicolumn{8}{|c|}{ Change between 2010-2016 } \\
\hline $\begin{array}{l}\text { Change } \\
\text { of std. } \\
\text { gradient }\end{array}$ & $-13.13 \%$ & $-7.67 \%$ & $-8.28 \%$ & -8.75 & $-10.24 \%$ & $-12.28 \%$ & $0.75 \%$ \\
\hline
\end{tabular}

Source: Data based on European Commission 2019 and OECD 2019. 
The changes of the standardized gradients between 2010 and 2016 are negative on all cooperation partners except a slight positive value for cooperating with government/public research institutes. These mainly negative standardized gradients indicate that the share of cooperating SMEs compared to MNEs has increased stronger. It can thus be observed that the gap between SMEs and MNEs that cooperate is shrinking. At a reduction in the standardized gradient of $12.28 \%$, the greatest convergence was achieved in the area of cooperation with universities, followed by cooperation with competitors $(-10.24 \%)$ and customers $(-8.75 \%)$.

With regard to the third research question - the clarification of successful cooperation strategies and the use of formal IP protection - the correlation analysis (see Table 1) is used once again.

The correlation analysis shows positive, strongly significant correlation coefficients between value added per GDP and the share of companies that cooperated in 2016. This refers to all cooperation partners (lowest Pearson correlation coefficient of 0.373 ), except for cooperation with competitors, where no significant correlation can be found. Regarding the correlation between funding and value added per GDP, no relationship can be established apart from a positive significance with EU funding (0.277). At the same time, there are highest significant correlations between value added per GDP and the expenditure on innovation per GDP $(0,604)$ as well as expenditure on in-house $R \& D(0.496)$ and external R\&D per GDP $(0.543)$.

With regard to successful cooperation strategies, a highly significant, positive correlation between value added per GDP and the share of companies using patents $(0.453)$ can be observed. The correlation between value added per GDP and the share of companies using industrial designs is only moderate significant (0.287), whereas there is no significant correlation between value added per GDP and the share of companies using trademarks.

\section{Discussion}

The characteristics of cooperation in general and in terms of cooperation partners are relatively unknown, especially for SMEs. The literature on innovation on the one hand mainly focuses on MNEs and on the other hand Industry 4.0 maturity models hardly give SMEs any consideration and lack a factor for measuring cooperation and alliances (Hossain 2015, Mittal et al. 2018, West and Boger 2014). For this reason, an individual approach has been developed that enables the analysis of cooperation in terms of their characteristics, its changes over the last years and successful strategies. This framework was applied to analyze secondary data, whereby correlations between various variables were found.

\section{Main Results and Relation to Literature Findings}

Firstly, MNEs are more cooperative than small companies based on the share of cooperating companies. Significant, positive correlations between company size and the share of companies that cooperate were identified for all examined 
cooperation partners (enterprises within the enterprise group, suppliers, customers, competitors and universities).

This is consistent with the findings of Teirlinck and Spithoven and Van der Vrande et al. according to which SMEs have a lower degree of cooperation than MNEs (Teirlinck and Spithoven 2013, Van de Vrande et al. 2009). Batz and Hossain discuss a possible reason for this in the strategy. SMEs hardly bundle their internal structures to reduce risks in order to avoid failure in the long run (Batz et al. 2018, Hossain 2015). Another possible reason could be provided by the study of Müller et al. of 2017. According to this study, in which SMEs were surveyed, the greatest challenge of cooperating was identified in the lack of trust in the cooperation partner (Müller et al. 2017).

However, this finding is surprising in the sense that the broad literature cites clearly stronger reasons for the benefits of cooperation in innovation for SMEs. Hence, this stands in contrast to the corresponding lack of resources of SMEs (e.g. financial assets) and the necessary to engage in cooperation in order to minimise long-term risks (Donnet et al. 2010, Van der Vrande et al. 2009, Van Wijk et al. 2008). In addition, this conflicts with Van der Vrande et al., according to which a large internal R\&D department is seen as a strategic investment and entry barrier for competitors wherefore large companies rely more on internal R\&D (Van der Vrande et al. 2009).

Secondly, with an increasing share of companies that cooperate, an increasing use of formal IP protections can be recognized. This suggests that in the case of cooperation, companies may be trying to protect its intellectual property.

This is consistent with the study by Müller et al. according to which the lack of trust is one of the greatest challenges (Müller et al. 2017, Van der Vrande et al. 2009). Furthermore, Andries and Fames state that patenting in companies, especially SMEs, can be seen as an important strategy to exploit the success of innovation (Andries and Faems 2013).

In addition, the average share of companies cooperating decreased slightly in 2016 compared to 2010, indicating a marginal increase of protectionism. Especially the share of companies cooperating with customers, competitors or the government has decreased overall during this period.

The literatures only provide opposing arguments with regard to this observation. Hence, this is in direct contrast to Gassmann's observation that the opening-up of the innovation process is seen as an empirical trend (Gassmann 2006).

At the same time, the share of SMEs that cooperate has increased within the analyzed time period for all examined cooperation partners except of a governmental cooperation. This has the effect that the observed gap between small and large companies that cooperate is shrinking. This applies particularly to the areas of academic cooperation, cooperation with competitors and customers.

There is a consensus on this with Gassman et al.'s findings that SMEs are increasingly opening-up their innovation process (Gassmann et al. 2010). This is supported by the broad literature according to which SMEs, due to the lack of resources, have increased reasons for engaging in cooperation (Van der Vrande et al. 2009, Donnet et al. 2010, Van Wijk et al. 2008). In addition, this also represents 
Van de Vrande's argument that internal R\&D departments are seen as a strategic investment and that large companies therefore place more emphasis on internal R\&D (Van der Vrande et al. 2009). It is not surprising, however, that SMEs have intensified their cooperation especially in the field of academic cooperation. According to West and Boger, as well as Van de Vrande, universities have already taken an important place in external knowledge and have a significant impact on productivity in R\&D (Van de Vrande et al. 2009, West and Boger 2014).

Furthermore, companies' success (based on significant correlation with value added per GDP) within the analyzed period increased with the share of companies cooperating (apart from cooperation with competitors) using EU funding, IP protections (patents or industrial designs) or with expenditure on innovations (inhouse or external R\&D).

The studies by Bougrain and Haudeville and Gronum et al., which identified a positive correlation between innovation efficiency and participation in cooperation networks, are in line with this result (Gronum et al. 2012, Bougrain and Haudeville 2002). This is also supported by Wadhwa and Rao, according to which companies can operate highly profitably if they cooperate (Wadhwa and Rao 2003). Furthermore, Gassmann et al. also proved that open innovation is a way to increase the profitability of companies (Gassmann et al. 2010). Possible reasons for this can be seen in the better utilization of capacities and the so increased productivity (Saniuk and Saniuk 2018).

Nevertheless, this insight is, with regard to profitability, also in conflict with numerous studies. So, the observation contrasts with Enkel et al., West und Boger and Müller et al., according to which open innovation leads to higher coordination and control costs (Enkel et al. 2009, Müller et al. 2017, West and Boger 2014). In this argument, however, an additional return of cooperating is not considered.

All in all, the survey reveals significant correlations between several analyzed variables. This development suggests that SMEs will continue to increase their cooperation intensity in the future. Similar characteristics can be assumed in the tertiary sector. This assumption is based on Batz et al., according to which Industry 4.0 leads to the secondary sector increasingly adopting characteristics of the service sector (e.g. involvement of the customer in product development and stockless production) (Batz et al. 2018).

\section{Limitations of the Study}

However, there are several limitations on the study that need to be mentioned. Firstly, the analyzed dataset consists of country-specific data. This implicates that only a transfer of the results to company findings can be concluded.

Another limitation that comes along with the dataset is lying in a restricted time scope of available data. The study is based on data of the years of 2010 and 2016. However, this dataset represents a large and most up-to-date data in this context.

Furthermore, the findings of the study are based on the research with respect on the quantitative engaging in cooperation. The approach only binarily examines whether companies engage in cooperation or not. However, the qualitative 
character of cooperation, for example the strategic value of cooperation, is not taken into account.

Moreover, the data on company sizes only show ordinal scale levels, which is why the correlations only take rank correlations into account when considering correlation with company size.

\section{Further Research}

Based on the findings of the study, in particular due to the above-mentioned limitations, there are further fields for additional research. Firstly, Kolk et al. highlights the necessity of hyper-cooperation in ecosystems with numerous partners due to the increasing market challenges (Kolk et al. 2017). For this reason, it is not adequate to limit the focus to the binary level of cooperation. Instead, the quantitative level and the qualitative nature (e.g. regarding the level and strategic meaning of individual cooperation) should in principle be taken into account in further research and considered in greater depth.

Furthermore, through the argument of Batz et al., according to which the secondary sector increasingly adopts the characteristics of the service sector, the results of the analysis were transferred seamlessly to the tertiary sector (Batz et al. 2018). However, this assumption was not verified and should be checked based on the framework in an additional examination.

In addition, the ongoing trend of the opening-up of SMEs should continue to be monitored. This might provide further findings on the opening-up of the innovation process of companies.

\section{Conclusions}

The aim of the study was to determine whether SMEs rely more on cooperation in product and process innovation than MNEs in the context of the change to Industry 4.0 or not. In this context a slightly increasing protectionism can be seen, whereby MNEs so far engage more intensively in cooperation than SMEs. Furthermore, an opening-up of the innovation process of SMEs can be observed. At the same time, a significant, positive correlation between cooperation and the economic success of companies can was revealed.

In this context it cannot easily be expected that there will be a further increase in protectionism in future. However, it can be expected that SMEs will intensify their cooperation more strongly in order to compensate their lack of resources.

So, the question now arises as to whether all companies should cooperate in any way with regard to increasing success? However, it should be expressly neglected to enter into random cooperation. Rather, it is necessary to weigh up which strategy is to be adopted in order to strengthen the innovativeness in the context of the transformation to Industry 4.0 and which strategic alliances seem appropriate in the individual context.

Since there are so far no empirical studies on the cooperation between companies in terms of different cooperation partners, the present study has a high 
relevance for future research. The study therefore assumes the role of a fundamental research allowing more detailed studies to be established. Based on this study, it is possible to assess and monitor the changing characteristics of cooperation in the future. In this regard, the identified knowledge gap in the literature search has been narrowed.

Furthermore, the aim of the study is to raise awareness that companies should not cooperate at any price. Instead, companies should weigh up which innovation and cooperation strategy they intend to adopt in the light of Industry 4.0 and which strategic alliances make sense in this regard in an individual aspect.

\section{References}

Acs Z, Audretsch D (1990) Innovation and small firms. Cambridge, MA: MIT Press.

Andries P, Faems D (2013) Patenting activities and firm performance: Does firm size matter? Journal of Product Innovation Management 30(6): 1089-1098.

Baldwin C, Henkel J (2014) Modularity and intellectual property protection. Strategic Management Journal 36(11): 1637-1655.

Batz A, Kunath M, Winkler H (2018) Discrepancies between cluster services and SMEs' needs constraining the creation of a culture of innovation amidst industry 4.0. Scientific Journal of Logistics 14(3): 387-405.

Baum G (2013) Innovationen als Basis der nächsten Industrierevolution [Innovation as basis for next industry revolution]. Industrie 4.0. Berlin, Heidelberg: Springer.

Bischoff J, Taphorn C, Wolter D, Braun N, Fellbaum M, Goloverov A et al. (2015) Erschliessen der Potenziale der Anwendung von Industrie 4.0 im Mittelstand. [Unlocking the potential of applying Industry 4.0 in the SME sector]. Studie im Auftrag des Bundesministeriums für Wirtschaft und Energie. Munich: Fraunhofer Society.

Bougrain F, Haudeville B (2002) Innovation: collaboration and SMEs internal research capacities. Research Policy Journal 31(5): 735-747.

Bundesministerium für Wirtschaft und Energie (2014) German Mittelstand: Motor der deutschen Wirtschaft. [German Mittelstand: engine of the German economy]. Berlin: Federal Ministry for Economic Affairs and Energy.

Ceccagnoli M, Graham S, Higgins MJ, Lee J (2010) Productivity and the role of complementary assets in firms' demand for technology innovations. Industrial and Corporate Change 19(3): 839-69.

Châlons C, Dufft N (2016) Die Rolle der IT als Enabler für Digitalisierung. [The role of IT as an enabler for digitization]. In Was treibt die Digitalisierung? F Abolhassan (ed). Wiesbaden: Springer Gabler.

Chesbrough H (2003) Open innovation: The new imperative for creating and profiting from technology. Boston, MA: Harvard Business School Press.

Chesbrough H (2006) Open business models: How to thrive in the new innovation landscape. Boston, MA: Harvard Business School Press.

Christensen J, Olesen MH, Kjaer JS (2005) The industrial dynamics of open innovation evidence from the transformation of consumer electronics. Research Policy 34(10): 1533-1549.

Cohen W, Nelson RR, Walsh JP (2002) Links and impacts: the influence of public research on industrial R\&D. Management Science 48(1): 1-23.

Dahlander L, Gann D (2010) How open is innovation? Research Policy 39(6): 699-709. 
Del Vecchio P, Di Minin A, Petruzzelli AM, Panniello U, Pirri S (2017) Big data for open innovation in SMEs and large corporations: Trends, opportunities, and challenges. Creativity and Innovation Management 27(1): 6-22.

Donnet T, Keast RL, Pickernell D (2010) Up the junction? Exploiting knowledge-based development through supply chain and SME cluster interactions. In KnowledgeBased Development for Cities and Societies: Integrated Multi-Level Approaches, $\mathrm{K}$ Metaxiotis, FJ Carrillo, T Yigitcanlar (eds), 179-195. Hershey PA: IGI Global.

Enkel E, Gassmann Oliver, Chesbrough HW (2009) Open R\&D and open innovation: exploring the phenomenon. $R \& D$ Management 39(4): 311-316.

European Commission (2014) Evaluation of the SME definition. Final report. Sevenoaks: EU publications.

European Commission (2019) Eurostat database. Retrieved from: https://bit.ly/32a8UPH. [Accessed 3 May 2019].

Ezell S (2018) Why manufacturing digitalization matters and how countries are supporting it. Information Technology \& Innovation Foundation.

Felser W, Kirsch A, Kletti J, Wießler J, Meuser D (2015) Industrie 4.0 Kompakt: Systeme für die kollaborative Produktion im Netzwerk. [Industrie 4.0 Kompakt: systems for collaborative production in the network]. Cologne: NetSkill Solutions.

Gassmann O (2006) Editorial Opening up the innovation process: towards an agenda. $R \& D$ Management 36(3): 223-228.

Gassmann O, Enkel E, Chesbrough HW (2010) The future of open innovation. $R \& D$ Management 40(3): 213-221.

Gronum S, Verreynne ML, Kastelle T (2012) The role of networks in small and mediumsized enterprise innovation and firm performance. Journal of Small Business Management 50(2): 257-282.

Hagedoorn, J (1993) Understanding the rationale of strategic technology partnering: interorganizational modes of cooperation and sectoral differences. Strategic Management Journal 14(5): 371-385.

Hossain M (2015) A review of literature on open innovation in small and medium-sized enterprises. Journal of Global Entrepreneurship Research 5(6): 2-12.

Kagermann H (2013) Recommendations for implementing the strategic initiative Industrie 4.0. Final Report of the Industrie 4.0 Working Group.

Kane G, Palmer D, Phillips A, Kiron D, Buckley N (2017) Achieving digital maturity. MIT Sloan Management Review \& Deloitte Digital. MIT Research Report.

Kieninger M, Mehanna, W, Michel U (2015) Auswirkungen der Digitalisierung auf die Unternehmenssteuerung [Influence of digisalization on company management]. Stuttgart: Schäffer-Poeschel Publishing.

Kolk M, Eagar R, Boulton C, Mira C, Schutz I (2017) Ecosystem innovation - The growth of hyper-collaboration in a fast-moving world. Prism (1): 12-25.

Meroño C, López N (2013) Understanding the drivers of organizational innovations. The Service Industries Journal 33(13-14): 1312-1325.

Mettler T (2011) Maturity Assessment Models: A design science research approach. International Journal of Society Systems Science 3(1/2): 81-98.

Michelino F, Lamberti E, Cammarano A, Caputo M (2014) Measuring open innovation in the bio-pharmaceutical industry. Creativity and Innovation Management 24(1): 4-28.

Mittal S, Khan MA, Romero D, Wuest T (2018) A critical review of smart manufacturing $\&$ industry 4.0 maturity models: implications for small and medium-sized enterprises (SMEs). Journal of Manufacturing Systems 49: 194-214.

Müller J, Maier L, Veile J, Voigt KI (2017) Cooperation strategies among SMEs for implementing industry 4.0. Hamburg: Proceedings of the Hamburg International Conference of Logistics (HICL). 
Nieves J, Quintana A, Osorio J (2016) Organizational knowledge and collaborative human resource practices as determinants of innovation. Knowledge Management Research \& Practice 14(3): 237-245

O'Regan N, Ghobadian A, Sims M (2006) Fast tracking innovation in manufacturing SMEs. Technovation 26(2): 251-261.

OECD (2019) OECD.Stat. Retrieved from: https://bit.ly/2Nfv4Mf. [Accessed 3May 2019].

Piccarozzi M, Aquilani B, Gatti C (2018) Industry 4.0 in management studies: a systematic literature review. Sustainability 10(10): 3821.

Piller F (2004). Innovation and value co-creation. Habilitation Thesis at Technical University of Munich.

Piller F, Reichwald R (2009) Interaktive Wertschöpfung und Open Innovation. [Interactive value creation and open innovation]. Berlin: Springer.

Piller F, Möslein K, Ihl C, Reichwald R (2017) Interaktive Wertschöpfung kompakt. Open Innovation, Individualisierung und neue Formen der Arbeitsteilung. [Interactive value added compact. Open innovation, individualization and new forms of division of labor]. Wiesbaden: Springer Gabler.

Platform I4.0 (2015) Von smarten Objekten und Maschinen. [Of smart objects and machines]. Retrieved from: https://bit.ly/36qJmRH. [Accessed 23 March 2019].

Rao P (2003) The economics of transaction costs: theory, methods and applications. Basingstoke: Palgrave Macmillan Publishing.

Reichwald R, Piller F (2009) Interaktive Wertschöpfung. Open Innovation, Individualisierung und neue Formen der Arbeitsteilung. [Interactive value creation. Open innovation, individualization and new forms of division of labor]. Wiesbaden: Springer Gabler.

Rigby D, Zook D (2002) Open-market innovation. Harvard Business Review 80(10): 8089.

Saniuk S, Saniuk A (2018) Challenges of industry 4.0 for production enterprises functioning within cyber industry networks. Sciendo Journal 26(4): 212-216.

Schikora T (2014) Open innovation. Der Matchmaker im Produktlebenszyklus. Viernull. Magazin für phygitalen Fortschritt 2: 33-36.

Schumpeter J (1934). The theory of economic development. Cambridge: Harvard University Press.

Semolic B, Steyn P (2018) Industry 4.0 collaborative research, innovation and development (RID) projects. Project Management World Journal 7(8): 1-27.

Spithoven A, Vanhaverbeke W, Roijakkers N (2013). Open innovation practices in SMEs and large enterprises. Small Business Economics 41(3): 537-562.

Stuermer M, Spaeth S, von Krogh GF (2009) Extending private collective innovation: a case study. $R \& D$ Management 39(2): 170-191.

Teirlinck P, Dumont M, Spithoven A (2010) Corporate decision making in R\&D outsourcing and the impact on internal R\&D employment intensity. Industrial and Corporate Change 19(6): 1741-68.

Teirlinck P, Spithoven A (2013). Research collaboration and R\&D outsourcing: Different R\&D personnel requirements in SMEs. Technovation 33(4-5): 142-153.

Tjahjono B, Esplugues C, Ares E, Pelaez G (2017) What does industry 4.0 means to supply chain? Procedia Manufacturing Journal 13: 1175-1182.

Van de Vrande V, de Jong JPJ, Vanhaverbeke W, Rochemont M (2009) Open innovation in SMEs: trends, motives and management challenges. Technovation 29(6-7): 423437. 
Van Wijk R, Jansen JJP, Lyles MA (2008) Inter-and intra-organizational knowledge transfer: a meta-analytic review and assessment of its antecedents and consequences. Journal of Management Studies 45(4): 830-853.

Vassiliadis M (2017) Digitalisierung und Industrie 4.0 Technik allein reicht nicht. [Digitalization and industry 4.0 technology alone is not enough]. Hannover: Deutsche Nationalbibliothek.

Vossen R (1998) Relative strengths and weaknesses of small firms in innovation. International Small Business Journal 16(3): 88-94.

Wadhwa S, Rao K (2003) Flexibility and agility for enterprise synchronization: knowledge and innovation management towards flexagility. Studies in Informatics and Control 12(2): 111-128.

West J, Boger M (2014) Leveraging external sources of innovation: a review of research on open innovation. Journal of Product Innovation Management 31(4): 814-831.

Zeng SX, Xie XM, Tam CM (2010) Relationship between cooperation networks and innovation performance of SMEs. Technovation 30(3): 181-194.

Zypries B (2017) Digitalisierung - Industrie 4.0 als Herausforderung für die deutsche Industrie. [Digitization - industry 4.0 as a challenge for German industry]. Hannover: Deutschen Nationalbibliothek. 